DOI: $10.29303 /$ jrpb.v9i2.219

ISSN 2301-8119, e-ISSN 2443-1354

Tersedia online di http://jrpb.unram.ac.id/

\title{
OPTIMALISASI BEBAN KERJA PADA INDUSTRI MAKANAN MENGGUNAKAN METODE WORKLOAD ANALYSIS (Sudi Kasus pada UD. MR-Jember)
}

\author{
Workload Optimization in Food Industry Using Workload Analysis Method \\ (A Case Study of UD. MR-Jember)
}

\author{
Ida Bagus Suryaningrat*), Nita Kuswardhani, Ninik Rizky Hastuti \\ Program Studi Teknologi Industri Pertanian, Fakultas Teknologi Pertanian, \\ Universitas Jember, Jember, Indonesia \\ Email $^{*}$ ): suryaningrat.ftp@unej.ac.id
}

Diterima: Juli 2021

Disetujui: September 2021

\begin{abstract}
UD. MR is one of food industries in Jember that produce a typical food, namely suwar-suwir. Recently, this industry was experiencing a shortage of workers due to workers resigning from their jobs. The workers seem tired of completing their work because of their increasing workload. This act indicated that the workers have a high workload in their daily activities. Most of the production process equipment uses a manual method with a high number of workers. This condition causes production error in some processes such as mixing, shaping, and packaging process. The research objectives were to evaluate the workload of workers and determine the optimum number of workers in UD. MR. The workload Analysis method was implemented to evaluate the workload of workers in this industry. WLA is a method for measuring the workload received by workers during their work. The WLA method requires data from the calculation of the percentage of productivity, Performance Rating and Allowance. The study showed that the workers in cooking, shaping, cutting, and packaging were categorized as high workload workers based on workload analysis. In contrast, workers at the packaging 1 (one) process were in the normal workload. Another result found that the optimal number of workers in the packaging 1 (one) process were 10 (ten) people, packaging 2 (two) needed 6 (six) people with additional incentives of Rp 20.200,- per person per month. Two people were required in the cooking process with additional incentives of $R p$ 477.490,per person per month. In the shaping process, 1 (one) person with additional incentives $R p$ 202.150,- per person per month was needed, and the cutting process required 2 (two) people with additional incentives $R p$ 85.150,- per person per month.
\end{abstract}

Keywords: workload; food industry; optimization; workload analysis

\begin{abstract}
ABSTRAK
UD. MR adalah salah satu industri di Kabupaten Jember yang memproduksi makanan tradusional suwar-suwir. Saat ini, UD. MR sedang mengalami kekurangan pekerja akibat
\end{abstract}


beberapa pekerja yang mengundurkan diri dari pekerjaan. Para pekerja tampak kelelahan dalam menyelesaikan pekerjaannya dikarenakan beban kerjanya yang semakin bertambah. Hal ini merupakan indikasi dari tingginya beban kerja yang diterima para pekerja. Proses produksi di UD. MR juga masih menggunakan alat-alat manual sehingga sangat membutuhkan tenaga manusia. Akibatnya, cukup banyak terdapat kesalahan yang dilakukan oleh para pekerja, seperti pencampuran rasa yang ditambahkan kurang merata, bentuk suwar-suwir yang tidak seragam dan kemasan yang kurang rapi. Tujuan penelitian yaitu mengukur beban kerja dari pekerja dan menentukan jumlah tenaga kerja optimal di UD. MR. Metode penelitian yaitu WLA (Workload Analysis). WLA adalah suatu metode untuk mengukur beban kerja yang diterima pekerja selama melakukan pekerjaannya. Metode WLA membutuhkan data hasil perhitungan persentase produktif, Performance Rating dan Allowance. Hasil penelitian menunjukkan berdasarkan Workload Analysis, beban kerja dari pekerja di bagian pemasakan, pencetakan, pemotongan, dan pengemasan 2 termasuk dalam beban kerja tinggi. Sedangkan pekerja di bagian pengemasan 1 termasuk dalam beban kerja normal. Jumlah pekerja yang optimal pada bagian pengemasan 1 sebanyak 10 orang, pengemasan 2 sebanyak 6 orang dengan tambahan insentif sebesar Rp 20.200 per orang per bulan, pemasakan sebanyak 2 dengan tambahan insentif sebesar Rp 477.490 per orang per bulan, pencetakan sebanyak 1 orang dengan tambahan insentif sebesar Rp 202.150 per orang per bulan dan pemotongan sebanyak 2 orang dengan tambahan insentif sebesar Rp 85.150 per orang per bulan.

Kata kunci: beban kerja; industri makanan; optimalisasi; workload analysis

\section{PENDAHULUAN}

\section{Latar Belakang}

Suwar-suwir adalah makanan khas yang biasanya dijadikan sebagai oleh-oleh dari kota Jember. Suwar-suwir terbuat dari bahan dasar tape yang dimasak dengan menambahkan gula dan perasa di dalamnya, kemudian didinginkan dan dipotong membentuk balok kecil-kecil. Banyaknya minat konsumen terhadap produk suwarsuwir membuat bermunculan industri yang memproduksi suwar-suwir, sehingga persaingan pasar pun juga semakin tinggi. Salah satu industri yang memproduksi suwar-suwir yaitu UD. MR yang berada di Kecamatan Ajung, Kabupaten Jember.

Sebagai suatu industri, untuk dapat mencapai tujuan yang diinginkan harus mempunyai manajemen yang baik salah satunya, yaitu manajemen sumber daya manusia. UD. MR mempunyai jumlah pekerja sebanyak 21 orang dengan produksi per hari kurang lebih 3,5 kwintal. UD. MR sangat bergantung pada tenaga manusia karena dalam proses produksinya masih menggunakan alat-alat manual. Dari observasi yang dilakukan di UD. MR, para pekerja juga tampak kelelahan dalam menyelesaikan pekerjaannya. Hal ini merupakan indikasi dari tingginya beban kerja yang diterima para pekerja. Beban kerja adalah seperangkat tuntutan tugas yang harus diselesaikan oleh pekerja dalam jangka waktu tertentu (Putra \& Prihatsanti, 2016). Semakin besar tingkat beban kerja pada karyawan dapat meningkatkan resiko kelelahan kerja (Maharja, 2015). Menurut pemilik usaha, UD. MR sedang mengalami kekurangan pekerja karena terdapat beberapa pekerja yang mengundurkan diri dari pekerjaannya. Jika terdapat satu pekerja yang tidak masuk, maka para pekerja akan sangat kewalahan dalam melakukan produksi.

Selain itu, dari proses produksi yang dikerjakan juga cukup banyak terdapat kesalahan yang dilakukan oleh para pekerja, seperti pencampuran rasa yang ditambahkan kurang merata, bentuk suwar-suwir yang tidak seragam dan kemasan yang kurang rapi. Menurut pemilik UD. MR juga belum pernah dilakukan pengukuran beban kerja dari para pekerja di UD. MR. Oleh karena itu, perlu dilakukan analisis beban kerja untuk mengetahui beban kerja dari para 
pekerja di UD. MR, sehingga nantinya dapat diketahui berapa jumlah tenaga kerja yang optimal di UD. MR.

\section{Tujuan}

Tujuan dari penelitian ini, yaitu mengukur beban kerja dari para pekerja di UD. MR dan menentukan jumlah tenaga kerja optimal di UD. MR.

\section{METODE PENELITIAN}

\section{Alat dan Bahan}

Alat yang digunakan pada penelitian ini adalah laptop, kamera handphone dan kuesioner. Sedangkan bahan yang digunakan, yaitu data primer dan data sekunder. Data primer diperoleh dari hasil wawancara, observasi dan kuisioner. Sedangkan data sekunder diperoleh dari studi pustaka seperti buku dan jurnal-jurnal yang dapat mendukung penelitian.

\section{Tahapan Penelitian}

Berikut merupakan diagram alir penelitian yang dapat dilihat pada Gambar 1 .

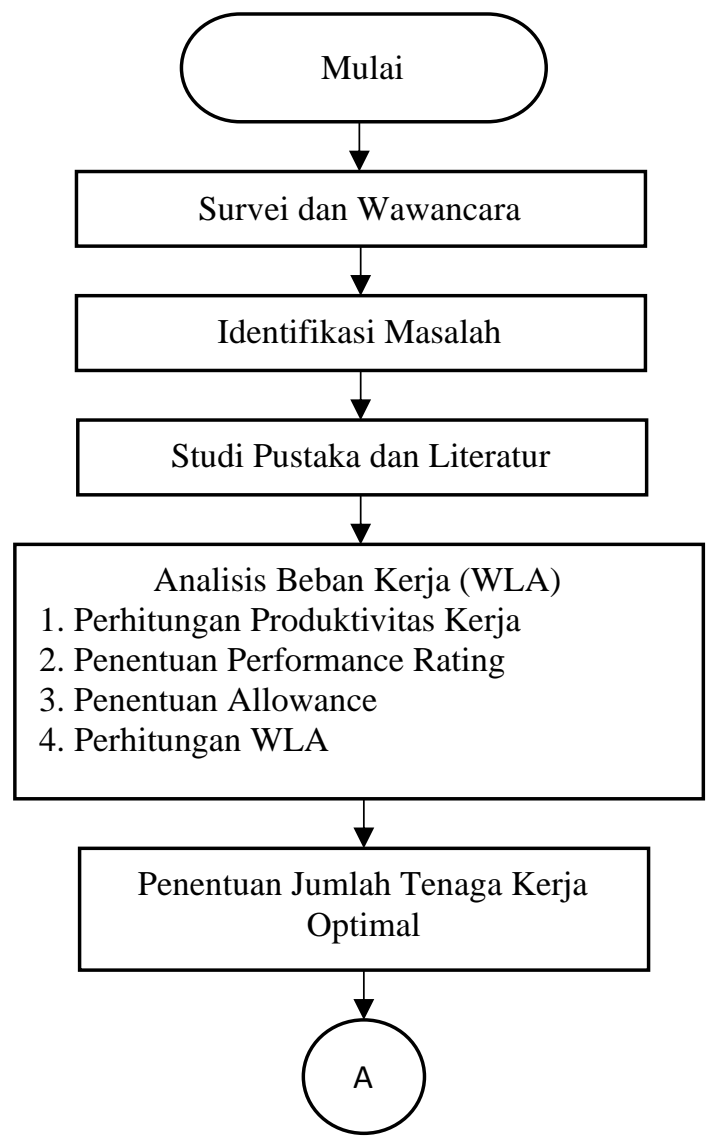

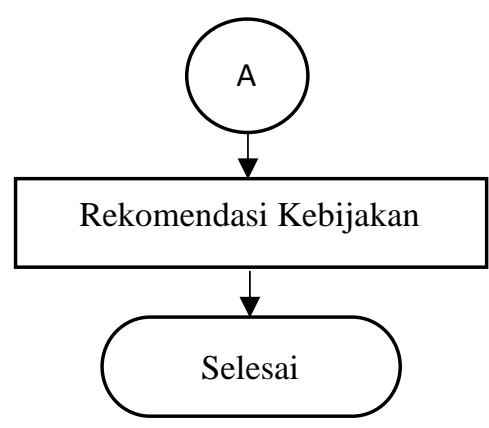

Gambar 1. Diagram Alir Penelitian

\section{Metode Pengumpulan Data}

Data yang dikumpulkan pada penelitian ini adalah sebagai berikut:

1. Data Gambaran Umum Proses Produksi UD. MR

Data gambaran umum proses produksi UD. MR didapatkan dari hasil wawancara dengan pihak industri.

2. Data Jumlah Pekerja

Data jumlah pekerja saat ini di UD. MR didapatkan dari dokumen perusahaan.

3. Data Job Description tiap Pekerjaan

Data Job description tiap pekerjaan didapatkan dari dokumen perusahaan.

4. Data Pekerja Produktif dan Nonproduktif Data pekerja produktif dan non-produktif didapatkan dari hasil pengamatan secara langsung terhadap 21 pekerja di UD. MR dengan menggunakan metode Work Sampling. Work Sampling merupakan metode pendekatan yang dapat digunakan untuk mengukur produktivitas dengan mudah (Yanti, 2017). Work Sampling juga dapat digunakan untuk mengetahui aktivitas produktif dan tidak produktif operator. Pengamatan yang dilakukan dalam Work Sampling ditentukan secara acak atau random (Rahdiana \& Agustiani, 2016).

5. Data Performance Rating

Data performance rating atau faktor penyesuaian didapatkan dari hasil pengukuran secara langsung terhadap 21 pekerja di UD. MR dengan menggunakan metode Westinghouse (Persamaan 1). Metode Westinghouse mengarahkan pada penilaian empat faktor yang dianggap menentukan kewajaran atau 
ketidakwajaran dalam bekerja, yaitu keterampilan, usaha, kondisi kerja dan konsistensi (Muzakir, et al., 2019).

$\mathrm{PR}=1+\mathrm{RF}$

Keterangan:

$\mathrm{PR}=$ Performance Rating

$\mathrm{RF}=$ Rating Factor

6. Data allowance

Data allowance atau faktor kelonggaran didapatkan dari hasil kuesioner terhadap 21 responden. Responden dari penelitian ini yaitu para pekerja di UD. MR. Hasil kuesioner yang didapat kemudian diolah menggunakan tabel ILO (Rachman, 2013).

\section{Metode Analisis Data}

Analisis data pada penelitian ini dilakukan dengan tahapan sebagai berikut:

1. Menghitung Persentase Produktif

Persentase produktif dihitung untuk mengetahui produktivitas pekerja. Persentase produktif dapat dicari dengan menggunakan Persamaan 2 (Yusup, 2019).

$\mathrm{PP}=\frac{\mathrm{Pr}}{\mathrm{Pe}} \times 100 \%$

Keterangan:

$\mathrm{PP}=$ Persentase produktif $(\%)$

Pr $=$ Jumlah produktif (Jumlah aktifitas yang sesuai Job Description pekerja)

$\mathrm{Pe}=$ Jumlah Pengamatan (Jumlah pengamatan aktifitas produktif maupun non produktif/hari)

2. Menghitung Beban Kerja

Perhitungan beban kerja didapatkan dari menghitung persentase produktif, Performance Rating dan Allowance. Persamaan 3 merupakan rumus yang digunakan dalam menghitung beban kerja (Arif, 2014).

$\mathrm{WLA}=\frac{\mathrm{PP} \times \mathrm{PR} \times \mathrm{TP} \times(1+\mathrm{Al})}{\mathrm{TP}}$.
Keterangan:

$\mathrm{PP}=$ Persentase Produktif $(\%)$

$\mathrm{PR}=$ Performance Rating

$\mathrm{TP}=$ Total Menit Pengamatan (menit)

$\mathrm{Al}=$ Allowance $(\%)$

3. Menghitung Jumlah Tenaga Kerja

Setelah didapatkan data beban kerja dan konsumsi energi dari para pekerja, maka selanjutnya dapat menghitung jumlah tenaga kerja yang dibutuhkan pada masing-masing bagian proses produksi dengan menggunakan Persamaan 4 dan 5 (Prabowo, et al., 2017).

$\mathrm{Rs}=\frac{\mathrm{T}}{\mathrm{P}}$.
$\mathrm{Ru}=\frac{\mathrm{T}}{\mathrm{U}}$

Keterangan:

Rs = Rata-rata beban kerja sekarang $(\%)$

$\mathrm{Ru}=$ Rata-rata beban kerja usulan (\%)

$\mathrm{T}=$ Total beban kerja (\%)

$\mathrm{P}=$ Jumlah pekerja

$\mathrm{U}=$ Jumlah tenaga kerja usulan

Menurut Budaya \& Muhsin (2018) beban kerja yang baik sebaiknya mendekati $100 \%$ atau dalam kondisi normal. Jika beban kerja yang diterima oleh pekerja melebihi $100 \%$, artinya beban pekerja terlalu tinggi dan perlu dilakukan penambahan pekerja. Sedangkan jika beban kerja yang diterima oleh pekerja kurang dari $100 \%$, maka perlu dilakukan pengurangan pekerja atau jika mendekati $100 \%$ artinya beban kerja dalam kondisi normal, sehingga tidak perlu dilakukan penambahan maupun pengurangan pekerja.

\section{HASIL DAN PEMBAHASAN}

\section{Proses Produksi}

Produksi suwar-suwir di UD. MR dilakukan dengan beberapa proses. Berikut merupakan gambaran proses produksi suwar-suwir yang dapat dilihat pada Gambar 2. 


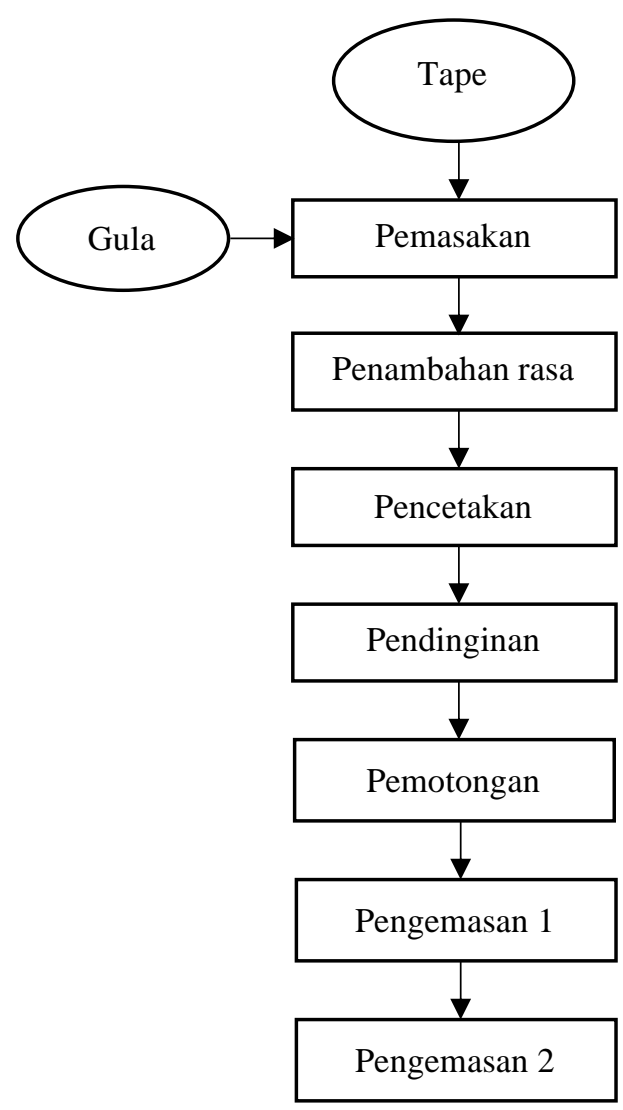

Gambar 2. Proses Produksi Suwar Suwir

Menurut Arianti, et al., (2014), salah satu keistimewaan suwar-suwir adalah proses pengolahannya yang masih sederhana. Meskipun proses pengolahannya masih sederhana dan tidak menggunakan bahan pengawet, suwar-suwir tetap istimewa karena dapat bertahan hingga 9 bulan.

\section{Tenaga Kerja}

UD. MR memiliki tenaga kerja sebanyak 21 orang. Responden dalam penelitian ini meliputi semua pekerja di UD. MR. Tabel 1 merupakan rekapitulasi pekerja yang menjadi responden pada penelitian ini.

Berdasarkan Tabel 1 dijelaskan total tenaga kerja sebanyak 21 orang. Pekerja berjenis kelamin perempuan berada di bagian pengemasan, sedangkan pekerja berjenis kelamin laki-laki berada di bagian pengolahan. Usia responden laki-laki berkisar antara 23 tahun sampai 33 tahun, karena pekerjaan tersebut membutuhkan banyak tenaga sehingga membutuhkan pekerja dengan tenaga yang kuat.

Tabel 1. Rekapitulasi Responden

\begin{tabular}{ccccc}
\hline No. & Nama & Kode & Bagian & Usia \\
\hline 1 & AH & A1 & Pengemasan 1 & 35 \\
2 & Ai & A2 & Pengemasan 1 & 34 \\
3 & Ern & A3 & Pengemasan 1 & 35 \\
4 & SR & A4 & Pengemasan 1 & 40 \\
5 & Lu & A5 & Pengemasan 1 & 50 \\
6 & Az & A6 & Pengemasan 1 & 48 \\
7 & Li & A7 & Pengemasan 1 & 30 \\
8 & S H & A8 & Pengemasan 1 & 65 \\
9 & Mu & A9 & Pengemasan 1 & 42 \\
10 & Nu & A10 & Pengemasan 1 & 31 \\
11 & Nur & B1 & Pengemasan 2 & 20 \\
12 & Rin & B2 & Pengemasan 2 & 20 \\
13 & N K & B3 & Pengemasan 2 & 55 \\
14 & Eli & B4 & Pengemasan 2 & 30 \\
15 & Si S & B5 & Pengemasan 2 & 28 \\
16 & Von & B6 & Pengemasan 2 & 25 \\
17 & A W & C1 & Pemasakan & 23 \\
18 & Mar & C2 & Pemasakan & 33 \\
19 & Rof & D1 & Pencetakan & 29 \\
20 & A I & E1 & Pemotongan & 27 \\
21 & Al Im & E2 & Pemotongan & 25 \\
\hline Sumbra & UD MR $($ data diolah) & \\
\hline
\end{tabular}

Sumber: UD. MR (data diolah)

Menurut Sutan, et al., (2019), besar tenaga yang digunakan seseorang dalam melakukan aktivitas berbeda-beda sesuai dengan beban kerjanya. Sedangkan usia responden perempuan mulai dari 20 tahun sampai dengan 66 tahun, hal ini karena skill yang dibutuhkan dari pekerjaan ini yaitu kecepatan tangan dalam mengemas suwarsuwir. Sehingga, usia tidak begitu diperhitungkan dalam pekerjaan ini.

\section{Job Description}

Jabaran Job Description masingmasing bagian produksi dapat dilihat pada Tabel 2. 
Tabel 2. Job Description setiap bagian proses produksi

\begin{tabular}{|c|c|c|}
\hline No. & Bagian & Job Description \\
\hline 1. & Pemasakan & $\begin{array}{l}\text { Mencampurkan tape } \\
\text { dengan gula dan dimasak } \\
\text { pada tungku atau wajan } \\
\text { sampai memadat. }\end{array}$ \\
\hline 2. & Pencetakan & $\begin{array}{l}\text { Menambahkan varian } \\
\text { rasa pada adonan dan } \\
\text { diaduk sampai tercampur }\end{array}$ \\
\hline & & $\begin{array}{l}\text { rata. Memindahkan } \\
\text { adonan suwar- suwir } \\
\text { yang sudah matang ke } \\
\text { wadah atau cetakan dan } \\
\text { diratakan sampai adonan } \\
\text { terisi penuh dalam } \\
\text { cetakan. }\end{array}$ \\
\hline 3. & Pemotongan & $\begin{array}{l}\text { Memotong suwar-suwir } \\
\text { dari cetakan besar ke } \\
\text { ukuran yang lebih kecil. }\end{array}$ \\
\hline 4. & Pengemasan 1 & $\begin{array}{l}\text { Mengemas suwar-suwir } \\
\text { yang sudah jadi ke } \\
\text { kemasan plastik yang } \\
\text { sudah disediakan. }\end{array}$ \\
\hline 5. & Pengemasan 2 & $\begin{array}{l}\text { Mengemas suwar suwir } \\
\text { yang sudah dibungkus } \\
\text { plastik dengan kemasan } \\
\text { kertas. }\end{array}$ \\
\hline
\end{tabular}

Sumber: UD. MR

\section{Perhitungan Produktivitas Kerja}

Perhitungan produktivitas kerja dilakukan untuk mengetahui persentase produktif dari para pekerja. Pada penelitian ini, jumlah pengamatan yang dilakukan setiap harinya sebanyak 56 pengamatan dengan waktu pengamatan selama 18 hari. Pengamatan dilakukan selama waktu kerja yaitu 7 jam, mulai pukul $06.00 \mathrm{~s} / \mathrm{d} 14.00$ WIB dengan waktu istirahat pada pukul $12.00 \mathrm{~s} / \mathrm{d} 13.00 \mathrm{WIB}$. Dari pengamatan yang telah dilakukan pada masing-masing pekerja, maka didapatkan persentase produktivitas yang ditunjukkan oleh Tabel 3.

Tabel 3 menjelaskan rata-rata tingkat produktivitas masing-masing pekerja selama 18 hari pengamatan. Aktivitas produktif adalah aktivitas yang dilakukan sesuai dengan job description masingmasing bagian pekerjaan yang telah ditentukan. Sedangkan aktivitas non produktif adalah aktivitas yang tidak ada pada job description dan tidak menghasilkan nilai tambah pada peningkatan kualitas proses produksi (Guntar dalam (Wibawa, et al., 2014)). Aktivitas non produktif dari para pekerja antara lain meliputi: berbincang dengan sesama rekan kerja, pergi ke kamar kecil, makan, minum, dan membuka handphone.

Tabel 3. Rekapitulasi Hasil Pengamatan Produktivitas Pekerja

\begin{tabular}{ccccc}
\hline No & Kode & Bagian & $\begin{array}{c}\text { Rata- } \\
\text { Rata }\end{array}$ & $\begin{array}{c}\text { Persentase } \\
\text { Produktif } \\
(\%)\end{array}$ \\
\hline 1 & A1 & Pengemasan 1 & 0,701 & 70,1 \\
2 & A2 & Pengemasan 1 & 0,700 & 70 \\
3 & A3 & Pengemasan 1 & 0,637 & 63,7 \\
4 & A4 & Pengemasan 1 & 0,626 & 62,6 \\
5 & A5 & Pengemasan 1 & 0,630 & 63 \\
6 & A6 & Pengemasan 1 & 0,627 & 62,7 \\
7 & A7 & Pengemasan 1 & 0,700 & 70 \\
8 & A8 & Pengemasan 1 & 0,649 & 64,9 \\
9 & A9 & Pengemasan 1 & 0,631 & 63,1 \\
10 & A10 & Pengemasan 1 & 0,623 & 62.3 \\
11 & B1 & Pengemasan 2 & 0,684 & 68,4 \\
12 & B2 & Pengemasan 2 & 0,688 & 68,8 \\
13 & B3 & Pengemasan 2 & 0,770 & 77 \\
14 & B4 & Pengemasan 2 & 0,699 & 69,9 \\
15 & B5 & Pengemasan 2 & 0,714 & 71,4 \\
16 & B6 & Pengemasan 2 & 0,679 & 67,9 \\
17 & C1 & Pemasakan & 0,864 & 86,4 \\
18 & C2 & Pemasakan & 0,868 & 86,8 \\
19 & D1 & Pencetakan & 0,771 & 77,1 \\
20 & E1 & Pemotongan & 0,715 & 71,5 \\
21 & E2 & Pemotongan & 0,712 & 71,2 \\
\hline Sum & & & \\
\hline
\end{tabular}

Sumber: Hasil Perhitungan

Dari Tabel 3 dapat dilihat bahwa produktivitas kerja yang paling tinggi terdapat pada pekerja bagian pemasakan. Hal ini karena pekerja di bagian pemasakan membutuhkan banyak tenaga untuk memasak adonan suwar-suwir kurang lebih 3 jam secara terus menerus. Sehingga, pekerja tidak dapat banyak melakukan aktivitas non produktif. Sedangkan produktivitas yang paling rendah terdapat pada pekerja bagian pengemasan 1 . Hal ini karena bagian pengemasan 1 adalah bagian dengan pekerjaan yang lebih membutuhkan kecepatan tangan dalam mengemas suwarsuwir sehingga pekerjaan lebih mudah dan lebih banyak aktivitas non produktif yang dilakukan. 


\section{Penentuan Performance Rating}

Performance Rating dilakukan untuk memberikan penilaian terhadap keahlian seorang pekerja. Data performance rating didapatkan dari hasil pengukuran secara langsung dengan menggunakan metode Westinghouse. Metode Westinghouse mengarahkan pada penilaian 4 faktor yang dianggap menentukan kewajaran atau ketidakwajaran dalam bekerja, yaitu keterampilan, usaha, kondisi kerja dan konsistensi (Muzakir, et al., 2019). Tabel 4 merupakan rekapitulasi hasil perhitungan Performance Rating setiap pekerja yang diteliti.

Tabel 4. Rekapitulasi Hasil Penentuan Performance Rating

\begin{tabular}{|c|c|c|c|c|c|c|c|c|}
\hline \multirow[b]{2}{*}{ No } & \multirow[b]{2}{*}{ Kode } & \multirow[b]{2}{*}{ Bagian } & \multicolumn{4}{|c|}{ Performance Rating } & \multirow{2}{*}{$\begin{array}{l}\text { Rating } \\
\text { Factor }\end{array}$} & \multirow{2}{*}{$\begin{array}{c}\text { Performance } \\
\text { Rating }\end{array}$} \\
\hline & & & Keterampilan & Usaha & $\begin{array}{c}\text { Kondisi } \\
\text { Kerja }\end{array}$ & Konsistensi & & \\
\hline 1 & $\mathrm{~A} 1$ & Pengemasan 1 & 0,11 & 0,08 & 0 & 0,01 & 0,20 & 1,20 \\
\hline 2 & A 2 & Pengemasan 1 & 0,11 & 0,08 & 0 & 0,01 & 0,20 & 1,20 \\
\hline 3 & A3 & Pengemasan 1 & 0,11 & 0,08 & 0 & 0,01 & 0,20 & 1,20 \\
\hline 4 & A4 & Pengemasan 1 & 0,11 & 0,08 & 0 & 0,01 & 0,20 & 1,20 \\
\hline 5 & A5 & Pengemasan 1 & 0,11 & 0,08 & 0 & 0,01 & 0,20 & 1,20 \\
\hline 6 & A6 & Pengemasan 1 & 0,11 & 0,08 & 0 & 0,01 & 0,20 & 1,20 \\
\hline 7 & A7 & Pengemasan 1 & 0,11 & 0,08 & 0 & 0,01 & 0,20 & 1,20 \\
\hline 8 & A8 & Pengemasan 1 & 0,11 & 0,08 & 0 & 0,01 & 0,20 & 1,20 \\
\hline 9 & A9 & Pengemasan 1 & 0,11 & 0,08 & 0 & 0,01 & 0,20 & 1,20 \\
\hline 10 & $\mathrm{~A} 10$ & Pengemasan 1 & 0,11 & 0,08 & 0 & 0,01 & 0,20 & 1,20 \\
\hline 11 & $\mathrm{~B} 1$ & Pengemasan 2 & 0,13 & 0,08 & 0 & 0,01 & 0,22 & 1,22 \\
\hline 12 & B2 & Pengemasan 2 & 0,13 & 0,08 & 0 & 0,01 & 0,22 & 1,22 \\
\hline 13 & B3 & Pengemasan 2 & 0,13 & 0,08 & 0 & 0,01 & 0,22 & 1,22 \\
\hline 14 & B4 & Pengemasan 2 & 0,13 & 0,08 & 0 & 0,01 & 0,22 & 1,22 \\
\hline 15 & B5 & Pengemasan 2 & 0,13 & 0,08 & 0 & 0,01 & 0,22 & 1,22 \\
\hline 16 & B6 & Pengemasan 2 & 0,13 & 0,08 & 0 & 0,01 & 0,22 & 1,22 \\
\hline 17 & $\mathrm{C} 1$ & Pemasakan & 0,08 & 0,05 & 0 & 0,01 & 0,14 & 1,14 \\
\hline 18 & $\mathrm{C} 2$ & Pemasakan & 0,08 & 0,05 & 0 & 0,01 & 0,14 & 1,14 \\
\hline 19 & D1 & Pencetakan & 0,03 & 0,05 & 0 & 0,01 & 0,09 & 1,09 \\
\hline 20 & E1 & Pemotongan & 0,03 & 0,05 & 0 & 0,01 & 0,09 & 1,09 \\
\hline 21 & E2 & Pemotongan & 0,03 & 0,05 & 0 & 0,01 & 0,09 & 1,09 \\
\hline
\end{tabular}

Sumber: Hasil Perhitungan

Dari penilaian performance rating para pekerja, didapatkan rating faktor seperti pada Tabel 4 dengan penilaian tertinggi didapatkan oleh pekerja bagian pengemasan 2 dengan nilai performance rating sebesar 1,22. Hal ini karena keterampilan pekerja pada bagian ini yang paling baik daripada bagian lain yaitu keterampilan kecepatan tangannya sehingga dapat menyelesaikan pekerjaan dengan cepat. Para pekerja tampak seperti terlatih dengan baik, gerakan-gerakannya sangat cepat dan terkesan sangat otomatis. Penilaian terendah didapatkan oleh para pekerja bagian pencetakan dan pemotongan dengan nilai performance rating sebesar 1,09. Hal ini karena kurang terampilnya pekerja di bagian tersebut yang dapat dilihat dari pekerjaannya yang masih banyak terdapat kecacatan seperti bentuk suwarsuwir yang tidak seragam dan warna suwarsuwir yang kurang merata. 


\section{Penentuan Allowance}

Allowance atau faktor kelonggaran adalah kelonggaran waktu yang diberikan kepada tenaga kerja untuk keperluan pribadi, mengurangi kelelahan dan hal-hal lain yang tidak terduga (Sabrini, et al., 2013). Faktor kelonggaran didapatkan dari hasil kuesioner terhadap para pekerja. Hasil kuesioner yang didapat kemudian diolah menggunakan tabel ILO.

Tabel 5. Rekapitulasi Hasil Faktor Kelonggaran

\begin{tabular}{|c|c|c|c|c|c|c|c|c|c|c|}
\hline \multirow{2}{*}{ No } & \multirow{2}{*}{ Kode } & \multirow{2}{*}{ Bagian } & \multicolumn{7}{|c|}{ Allowance } & \multirow{2}{*}{ Total Allowance (\%) } \\
\hline & & & $\mathrm{A}$ & $\mathrm{B}$ & $\mathrm{C}$ & $\mathrm{D}$ & $\mathrm{E}$ & $\mathrm{F}$ & $\mathrm{G}$ & \\
\hline 1 & A1 & Pengemasan 1 & 6 & 0 & 0 & 6 & 6 & 5 & 0 & 23 \\
\hline 2 & $\mathrm{~A} 2$ & Pengemasan 1 & 6 & 0 & 0 & 6 & 6 & 5 & 0 & 23 \\
\hline 3 & A3 & Pengemasan 1 & 6 & 0 & 0 & 6 & 6 & 5 & 0 & 23 \\
\hline 4 & A4 & Pengemasan 1 & 6 & 0 & 5 & 6 & 6 & 5 & 0 & 28 \\
\hline 5 & A5 & Pengemasan 1 & 6 & 0 & 5 & 6 & 6 & 5 & 0 & 28 \\
\hline 6 & A6 & Pengemasan 1 & 6 & 0 & 0 & 7,5 & 6 & 0 & 0 & 19,5 \\
\hline 7 & A7 & Pengemasan 1 & 6 & 0 & 0 & 7,5 & 6 & 0 & 0 & 19,5 \\
\hline 8 & A8 & Pengemasan 1 & 6 & 0 & 0 & 7,5 & 6 & 0 & 0 & 19,5 \\
\hline 9 & A9 & Pengemasan 1 & 6 & 0 & 0 & 7,5 & 6 & 0 & 0 & 19,5 \\
\hline 10 & A10 & Pengemasan 1 & 6 & 0 & 0 & 7,5 & 6 & 5 & 0 & 24,5 \\
\hline 11 & B1 & Pengemasan 2 & 6 & 0 & 0 & 7,5 & 5 & 0 & 0 & 18,5 \\
\hline 12 & B2 & Pengemasan 2 & 6 & 0 & 0 & 7,5 & 5 & 0 & 0 & 18,5 \\
\hline 13 & B3 & Pengemasan 2 & 6 & 0 & 0 & 7,5 & 5 & 0 & 0 & 18,5 \\
\hline 14 & B4 & Pengemasan 2 & 6 & 0 & 0 & 7,5 & 5 & 0 & 0 & 18,5 \\
\hline 15 & B5 & Pengemasan 2 & 6 & 0 & 0 & 7,5 & 5 & 0 & 0 & 18,5 \\
\hline 16 & B6 & Pengemasan 2 & 6 & 0 & 0 & 7,5 & 5 & 0 & 0 & 18,5 \\
\hline 17 & $\mathrm{C} 1$ & Pemasakan & 20 & 2,5 & 0 & 6 & 10 & 0 & 0 & 38,5 \\
\hline 18 & $\mathrm{C} 2$ & Pemasakan & 20 & 2,5 & 0 & 6 & 10 & 0 & 0 & 38,5 \\
\hline 19 & D1 & Pencetakan & 19 & 2,5 & 0 & 6 & 10 & 0 & 0 & 37,5 \\
\hline 20 & E1 & Pemotongan & 18 & 2,5 & 0 & 7,5 & 9 & 0 & 0 & 37,0 \\
\hline 21 & E2 & Pemotongan & 18 & 2,5 & 0 & 7,5 & 9 & 0 & 0 & 37,0 \\
\hline
\end{tabular}

Sumber: Hasil Perhitungan

Dari Tabel 5 dapat dilihat bahwa nilai Allowance tertinggi terdapat pada pekerja bagian pemasakan dengan nilai sebesar $38,5 \%$. Hal ini karena pekerjaannya membutuhkan banyak tenaga dan kurangnya pekerja di bagian pemasakan sehingga pekerja seringkali kewalahan dalam mengerjakan pekerjaannya. Pekerja harus berdiri selama waktu kerja dengan tangan yang terus mengaduk adonan. Selain itu, keadaan lingkungan seperti temperatur yang tinggi juga menambah ketidaknyamanan pekerja yang mengakibatkan kelelahan pada pekerja semakin meningkat. Oleh karena itu, dibutuhkan waktu kelonggaran yang tinggi untuk menghilangkan kelelahan dan ketegangan selama bekerja. Kelonggaran yang dimaksud adalah waktu istirahat untuk menghilangkan kelelahan dan memenuhi kebutuhan pribadi seperti minum, makan, pergi ke kamar kecil, duduk istirahat, mencuci muka dan lain sebagainya. Nilai Allowance terendah terdapat pada pekerja bagian pengemasan 2 dengan nilai sebesar $18,5 \%$. Hal ini karena pekerja di bagian pengemasan 2 cukup banyak dan melakukan pekerjaan dengan posisi duduk serta mengandalkan kecepatan tangan dalam mengemas produk. Keadaan lingkungan seperti temperatur dan pencahayaan yang sangat baik juga menjadikan pekerja cukup 
nyaman sehingga mengurangi tingkat kelelahan para pekerja. Oleh karena itu, waktu kelonggaran yang dibutuhkan untuk menghilangkan kelelahan dan ketegangan selama bekerja lebih rendah daripada pekerja di bagian yang lain.

\section{Perhitungan Beban Kerja dengan Workload Analysis (WLA)}

Workload Analysis merupakan suatu cara untuk menghitung beban kerja suatu fungsi tertentu dalam perusahaan. Dari perhitungan ini kemudian dapat ditentukan berapa jumlah kebutuhan ideal pegawai yang dibutuhkan (Wardah dan Adrian, 2017).

Menurut Budaya \& Muhsin (2018) beban kerja yang baik sebaiknya mendekati $100 \%$ atau dalam kondisi normal. Jika beban kerja yang diterima oleh pekerja melebihi $100 \%$, artinya beban pekerja terlalu tinggi dan perlu dilakukan penambahan pekerja. Sedangkan jika beban kerja yang diterima oleh pekerja kurang dari $100 \%$, maka perlu dilakukan pengurangan pekerja atau jika mendekati $100 \%$ artinya beban kerja dalam kondisi normal sehingga tidak perlu dilakukan penambahan maupun pengurangan pekerja. Rekapitulasi hasil perhitungan beban kerja dari setiap bagian dapat dilihat pada Tabel 6 .

Dari Tabel 6 dapat dilihat bahwa pekerja di bagian pengemasan 1 mempunyai rata-rata beban kerja sebesar 96,07\%. Nilai ini lebih kecil atau mendekati batas optimal beban kerja yang telah ditentukan yaitu $100 \%$. Hal ini berarti beban kerja dalam kondisi normal sehingga tidak perlu dilakukan penambahan maupun pengurangan pekerja. Pekerja di bagian pengemasan 2 , pemasakan, pencetakan dan pemotongan mempunyai rata-rata beban kerja masing-masing sebesar 102,02\%, $136,73 \%, 115,55 \%$ dan $106,55 \%$. Nilai ini lebih besar dari batas optimal beban kerja yang telah ditentukan yaitu $100 \%$. Hal ini berarti beban kerja terlalu tinggi sehingga perlu dilakukan penambahan pekerja.

\section{Rekomendasi Jumlah Pekerja}

Tabel 7 merupakan rekapitulasi hasil perhitungan jumlah tenaga kerja yang optimal berdasarkan beban kerja dari para pekerja.

Tabel 6. Rekapitulasi Hasil Perhitungan Beban Kerja

\begin{tabular}{cccccc}
\hline No & Bagian & $\begin{array}{c}\text { Rata-Rata } \\
\text { \%Produktif }\end{array}$ & $\begin{array}{c}\text { Rata-Rata Performance } \\
\text { Rating }\end{array}$ & $\begin{array}{c}\text { Rata-rata } \\
\text { Allowance }(\%)\end{array}$ & $\begin{array}{c}\text { Rata-Rata Beban } \\
\text { Kerja }(\%)\end{array}$ \\
\hline 1 & Pengemasan 1 & 65,24 & 1,20 & 23 & 96,07 \\
2 & Pengemasan 2 & 70,57 & 1,22 & 19 & 102,02 \\
3 & Pemasakan & 86,60 & 1,14 & 39 & 136,73 \\
4 & Pencetakan & 77,10 & 1,09 & 38 & 115,55 \\
5 & Pemotongan & 71,35 & 1,09 & 37 & 106,55 \\
\hline
\end{tabular}

Sumber: Hasil Perhitungan

Tabel 7. Rekapitulasi Hasil Perhitungan Jumlah Tenaga Kerja Optimal

\begin{tabular}{ccccccc}
\hline No. & Bagian & $\begin{array}{c}\text { Jumlah } \\
\text { Pekerja } \\
\text { Sekarang }\end{array}$ & $\begin{array}{c}\text { Rata-Rata Beban } \\
\text { Kerja (\%) }\end{array}$ & $\begin{array}{c}\text { Rekomendasi } \\
\text { Jumlah Pekerja }\end{array}$ & $\begin{array}{c}\text { Jumlah Pekerja } \\
\text { Rekomendasi }\end{array}$ & $\begin{array}{c}\text { Rata-Rata Beban } \\
\text { Kerja (\%) }\end{array}$ \\
\hline 1 & Pengemasan 1 & 10 & 96,07 & 0 & 10 & 96,07 \\
2 & Pengemasan 2 & 6 & 102,02 & +1 & 7 & 87,44 \\
3 & Pemasakan & 2 & 136,73 & +1 & 3 & 91,16 \\
4 & Pencetakan & 1 & 115,55 & +1 & 2 & 57,78 \\
5 & Pemotongan & 2 & 106,55 & +1 & 3 & 71,03 \\
\hline
\end{tabular}

Sumber: Hasil perhitungan 
Berdasarkan Tabel 7 dapat dilihat bahwa hanya pekerja di bagian pengemasan 1 yang berada dalam kondisi normal sehingga tidak dibutuhkan penambahan maupun pengurangan pekerja. Sedangkan para pekerja di bagian pengemasan 2, pemasakan, pencetakan dan pemotongan memiliki rata-rata beban kerja diatas batas optimal sehingga dibutuhkan penambahan pekerja.

Pada bagian pengemasan 1 dengan rata-rata beban kerja sebesar $96,07 \%$, rekomendasi jumlah pekerja yang diberikan yaitu 0 atau tidak terdapat penambahan maupun pengurangan pekerja. Jadi, pekerja di bagian pengemasan 1 tetap sebanyak 10 orang. Pada bagian pengemasan 2 dengan rata-rata beban kerja sebesar 102,02\%, rekomendasi yang diberikan yaitu penambahan 1 orang pekerja. Jadi, jumlah pekerja pada bagian pengemasan 2 yang semula sebanyak 6 orang bertambah menjadi 7 orang.

Pada bagian pemasakan dengan ratarata beban kerja sebesar 136,73\%, rekomendasi yang diberikan yaitu penambahan 1 orang pekerja. Jadi, jumlah pekerja pada bagian pemasakan yang semula sebanyak 2 orang bertambah menjadi 3 orang. Pada bagian pencetakan dengan rata-rata beban kerja sebesar $115,55 \%$, rekomendasi yang diberikan yaitu penambahan 1 orang pekerja. Jadi, jumlah pekerja pada bagian pencetakan yang semula sebanyak 1 orang bertambah menjadi 2 orang. Pada bagian pemotongan dengan rata-rata beban kerja sebesar $106,55 \%$, rekomendasi yang diberikan yaitu penambahan 1 orang pekerja. Jadi, jumlah pekerja pada bagian pemotongan yang semula sebanyak 2 orang bertambah menjadi 3 orang.

\section{Rekomendasi Kebijakan}

Berdasarkan hasil yang didapat dalam penentuan jumlah tenaga kerja optimal, peneliti melakukan diskusi bersama pemilik UD. MR terkait kesanggupan pemilik melakukan penambahan pekerja.
Rekomendasi kebijakan yang dapat dilakukan antara lain:

1. Melakukan penambahan jumlah tenaga kerja sesuai dengan rekomendasi jumlah tenaga kerja

Berdasarkan hasil perhitungan beban kerja yang diterima, jumlah tenaga kerja yang dibutuhkan untuk mengurangi beban kerja adalah sebanyak empat orang yaitu satu pekerja di bagian pemasakan, satu pekerja di bagian pencetakan, satu pekerja di bagian pemotongan dan satu pekerja di bagian pengemasan 2 . Penambahan tenaga kerja ini memiliki resiko yaitu mengeluarkan gaji bagi satu orang tenaga kerja pada bagian pengemasan 2 sebesar Rp 1.000.000,- per bulan dan tiga orang tenaga kerja yaitu pada bagian pemasakan, pencetakan dan pemotongan masing-masing sebesar $\mathrm{Rp}$ 1.300.000,- per bulan.

2. Tidak melakukan penambahan jumlah tenaga kerja, tetapi memberikan insentif kepada pekerja berdasarkan kelebihan beban kerjanya sebagai kompensasi atas tingginya beban kerja dari pekerja.

Jumlah insentif yang diberikan kepada pekerja diperoleh dari hasil kali kelebihan beban kerja dengan gaji pekerja (Aulia, 2018). Gaji pekerja bagian pengemasan sebesar $\mathrm{Rp}$ 1.000.000,- per bulan dan bagian pengolahan sebesar Rp 1.300.000,- per bulan.

Berdasarkan Tabel 8, pekerja di bagian pengemasan 1 tidak menerima insentif karena beban kerjanya tergolong beban kerja normal. Sedangkan pekerja di bagian pengemasan 2 menerima insentif sebesar Rp 20.200,- per orang per bulan. Pekerja di bagian pemasakan menerima insentif sebesar Rp 477.490,- per orang per bulan. Pekerja di bagian pencetakan menerima insentif sebesar Rp 202.150,- per orang per bulan. Pekerja di bagian pemotongan menerima insentif sebesar $\mathrm{Rp}$ 85.150 ,- per orang per bulan. 
Tabel 8. Pemberian Insentif Berdasarkan Kelebihan Beban Kerja

\begin{tabular}{llcccc}
\hline No & Bagian & $\begin{array}{c}\text { Jumlah Pekerja } \\
\text { Sekarang }\end{array}$ & $\begin{array}{c}\text { Rata-Rata } \\
\text { Beban Kerja } \\
(\%)\end{array}$ & $\begin{array}{c}\text { Kelebihan } \\
\text { Beban Kerja } \\
(\%)\end{array}$ & $\begin{array}{c}\text { Insentif } \\
\text { (per orang per bulan) }\end{array}$ \\
\hline 1 & Pengemasan 1 & 10 & 96,07 & 0 & 0 \\
2 & Pengemasan 2 & 6 & 102,02 & 2,02 & Rp 20.200 \\
3 & Pemasakan & 2 & 136,73 & 36,73 & Rp 477.490 \\
4 & Pencetakan & 1 & 115,55 & 15,55 & Rp 202.150 \\
5 & Pemotongan & 2 & 106,55 & 6,55 & Rp 85.150 \\
\hline
\end{tabular}

Sumber: Hasil Perhitungan

\section{KESIMPULAN DAN SARAN}

\section{Kesimpulan}

Berdasarkan Workload Analysis, beban kerja dari pekerja di bagian pemasakan, pencetakan, pemotongan dan pengemasan 2 termasuk dalam beban kerja tinggi. Sedangkan pekerja di bagian pengemasan 1 termasuk dalam beban kerja normal. Jumlah pekerja yang optimal pada pekerja bagian pengemasan 1 sebanyak 10 orang (tidak terdapat penambahan pekerja), pengemasan 2 sebanyak 6 orang namun memberikan tambahan insentif sebesar $\mathrm{Rp}$ 20.200,- per orang per bulan, pemasakan sebanyak 2 orang namun memberikan tambahan insentif sebesar Rp 477.490,- per orang per bulan, pencetakan sebanyak 1 orang namun memberikan tambahan insentif sebesar Rp 202.150,- per orang per bulan dan pemotongan sebanyak 2 orang namun memberikan tambahan insentif sebesar Rp 85.150 ,- per orang per bulan.

\section{Saran}

Berdasarkan penelitian yang telah dilakukan, saran yang dapat diberikan bagi industri yaitu jika penambahan pekerja tidak dapat dilakukan, industri dapat memberikan insentif kepada pekerja yang beban kerjanya terlalu tinggi.

\section{UCAPAN TERIMA KASIH}

Terima kasih kepada Program Studi Teknologi Industri Pertanian, Fakultas Teknologi Pertanian, Universitas Jember yang telah memberikan berbagai fasilitas selama penelitian, serta seluruh pekerja, manajemen dan pemilik UD. MR yang telah bersedia bekerjasama selama penelitian berlangsung.

\section{DAFTAR REFERENSI}

Arianti, G. K., Sukerti, N. W., \& Marsiti, C. I. R. (2014). Diversifikasi Tape Ubi Jalar Kuning Menjadi Suwar-suwir. Jurnal BOSAPARIS: Pendidikan Kesejahteraan Keluarga, 3(1).

Arif, R. (2014). Analisa Beban Kerja Dan Jumlah Tenaga Kerja Yang Optimal Pada Bagian Produksi Dengan Pendekatan Metode Work Load Analysis (WLA) Di PT. Surabaya Perdana Rotopack. Jawa Timur: Jurusan Teknik Industri, Universitas Pembangunan Nasional.

Aulia, N. (2018). Analisis Beban kerja Untuk Menentukan Jumlah Karyawan Optimal Pada UD. Nagawangi Alam Sejahtera. Jurnal Valtech, 1(1), 143148.

Budaya, P. W., \& Muhsin, A. (2018). Workload Analysis in Quality Control Department. Opsi, 11(2), 134. https://doi.org/10.31315/opsi.v11i2.2 554.

Maharja, R. (2015). Analisis Tingkat Kelelahan Kerja Berdasarkan Beban 
Kerja Fisik Perawat Di Instalasi Rawat Inap RSU Haji Surabaya. The Indonesian Journal of Occupational Safety and Health, 4(1), 93. https://doi.org/10.20473/ijosh.v4i1.20 15.93-102.

Muzakir, M., Irawan, H. T., \& Pamungkas, I. (2019). Pengukuran Waktu Kerja Karyawan Bengkel Toyota PT. Dunia Barusa Di Kota Banda Aceh. Jurnal Optimalisasi, 4(1), 21-29.

Prabowo, A., Setiawan, H., \& Umiyati, A. (2017). Analisa Beban Kerja Dan Penentuan Tenaga Kerja Optimal Dengan Pendekatan Work Load Analysis (WLA). Jurnal Teknik Industri, 5(1), 40-45.

Putra, M. T. P., \& Prihatsanti, U. (2016). Hubungan Antara Beban Kerja Dengan Intensi Turnover Pada Karyawan Di PT. "X”. Jurnal Empati, 5(2), 303-307.

Rachman, T. (2013). Penggunaan Metode Work Sampling untuk Menghitung Waktu Baku dan Kapasitas Produksi Karungan Soap Chip di PT. SA. Jurnal Inovasi, 9(1), 48-60.

Rahdiana, N., \& Agustiani, N. (2016). Analisis Beban Kerja Operator Finishing Sortir Dengan Metode Work Sampling (Studi Kasus Di PT . XZY). Industry Xplore, 1(1), 1-12.

Sabrini, A., Rambe, J., \& Wahyuni, D. (2013). Pengukuran Beban Kerja Karyawan Dengan Menggunakan Metode Swat (Subjective Workload Assessment Technique) Dan Work Sampling Di PT. XYZ. Jurnal Teknik Industri USU, 4(2), 6-13.

Sutan, S. M., Pratama, Y. A., Djoyowasito, G., \& Ahmad, A. M. (2019). Rancang Bangun Dan Uji Kinerja Mesin Perajang Tembakau Mesin Perajang
Tembakau Semi Mekanis Sistem Kayuh. Jurnal Ilmiah Rekayasa Pertanian Dan Biosistem, 7(2), 249255.

https://doi.org/10.29303/jrpb.v7i2.14 4.

Wardah, S. (2017). Penentuan Jumlah Karyawan Yang Optimal Pada Penanaman Lahan Kelapa Sawit Dengan Menggunakan Metode Work Load Analysis (WLA). Jurnal Teknik Industri: Jurnal Hasil Penelitian Dan Karya Ilmiah Dalam Bidang Teknik Industri, $\quad 3(1), \quad 46$. https://doi.org/10.24014/jti.v3i1.6150.

Wibawa, R. P. N., Sugiono, \& Efranto, R. Y. (2014). Analisis Beban Kerja Dengan Metode Workload Analysis Sebagai Pertimbangan Pemberian Insentif Pekerja (Studi Kasus di Bidang PPIP PT Barata Indonesia (Persero) Gresik). Jurnal Rekayasa Dan Manajemen Sistem Industri, 2(3), 672-683.

Yanti, G. (2017). Produktivitas Tenaga Kerja Dengan Metode Work Sampling Proyek Perumahan Di Kota Pekanbaru. SIKLUS: Jurnal Teknik Sipil, 3(2), 100-106.

https://doi.org/10.31849/siklus.v3i2.38 5.

Yusup, M. (2019). Perencanaan Tenaga Kerja Dengan Metode Analisis Beban Kerja Pada Departemen Packing (Studi Kasus PT. Unggul Bukit Kencana). Prosiding FRIMA (Festival Riset Ilmiah Manajemen Dan Akuntansi), 6681(2), 932-940. 